\title{
Retraction Note to: Superwideband Triple Notch Monopole Antenna for Multiple Wireless Applications
}

\author{
Manish Sharma ${ }^{1}$ \\ Published online: 1 October 2021 \\ ๑) Springer Science+Business Media, LLC, part of Springer Nature 2021
}

\section{Retraction Note to: Wireless Personal Communications (2019) 104:459-470 https://doi.org/10.1007/s11277-018-6030-9}

The Editor-in-Chief has retracted this article [1] because it significantly overlaps with a previously published article by Sharma.

Manish Sharma does not agree to this retraction. The other authors have not responded to correspondence regarding this retraction notice.

\section{Reference}

1. Sharma, M. (2019). Superwideband triple notch monopole antenna for multiple wireless applications. Wireless Personal Communications, 104, 459-470. https://doi.org/10.1007/s11277-018-6030-9

Publisher's Note Springer Nature remains neutral with regard to jurisdictional claims in published maps and institutional affiliations.

The original article can be found online at https://doi.org/10.1007/s11277-018-6030-9.

\section{Manish Sharma}

manishengineer1978@gmail.com

1 Department of Electronics and Communication Engineering, SGT University, Gurugram, India 